\title{
Our Experiences on Kyphosis and Scoliosis Surgery in Juvenile and Adolescent Patients During Pandemic Period
}

\section{Pandemi Sürecinde Juvenil ve Adolesanlarda Kifoz ve Skolyoz Cerrahisi Deneyimlerimiz}

\author{
DAdnan Yalçın Demirci \\ Bursa City Hospital, Department of Neurosurgery, Bursa, Turkey
}

\begin{abstract}
Aim: In this study, we aimed to contribute to the literature by sharing our experiences regarding the major spine surgeries we have applied to juvenile and adolescent patients during the Covid-19 pandemic process.

Material and Method: We retrospectively evaluated a total of 26 juvenile and adolescent idiopathic scoliosis and kyphosis patients we operated within a year from April 2020, when pandemic measures were implemented in our country up to April 2021.

Results: Any respiratory complications or symptoms and signs of Covid-19 were not observed in our patients in the preoperative and / or postoperative period.

Conclusion: During this pandemic period, it was ensured that major spine deformity surgeries in juvenile and adolescent patients were successfully managed for both our patients and our healthcare personnel.
\end{abstract}

Keywords: Adolescent, Covid-19, pandemic, scoliosis
Öz

Amaç: Biz bu çalışmada, Covid-19 pandemi sürecinde juvenil ve adolesanlara uyguladığımız major omurga cerrahileri ile ilgili tecrübelerimizi paylaşarak literatüre katkıda bulunmayı amaçladık.

Gereç ve Yöntem: Ülkemizde pandemi önlemlerinin uygulamaya başlandığı Nisan 2020'den Nisan 2021'e kadar geçen bir yıllık süreçte ameliyat ettiğimiz toplam 26 juvenil ve adelosan idiopatik skolyoz ve kifoz hastasını retrospektif olarak değerlendirdik.

Bulgular: Hastalarımızda preoperatifve/veya postoperatif dönemde solunumsal bir komplikasyon ya da Covid-19 semptom ve bulguları görülmedi.

Sonuç: Bu pandemi döneminde, juvenil ve adolesanlarda major omurga deformitesi ameliyatlarının hem hastalarımız hem de sağlık personelimiz açısından başarıı bir şekilde yönetilmesi sağlanmıştır.

Anahtar Kelimeler: Adolesan, Covid-19, pandemi, skolyoz 


\section{INTRODUCTION}

The coronavirus (Covid-19) pandemic has affected patients all over the world and doctors, nurses and other auxillary health professionals involved in the delivery of health services. ${ }^{[1]}$ Elective surgical interventions of many patients in all surgical branches worldwide have been postponed because of the increased burden of hospitals due to Covid-19 and the increased risk of complications caused by Covid-19. Operation time is an important factor for disease prognosis in juvenile and adolescent idiopathic scoliosis surgery. Studies have shown that waiting more than 6 months for surgery in juvenile and adolescent idiopathic scoliosis patients is a risk for progression of deformity. ${ }^{[2]}$ Delayed surgical treatment of deformity may lead to additional surgical procedures, prolonged operation time and greater amount of blood loss, and also may adversely affect the patient's psychology. ${ }^{[1,3,4]}$ Spine surgery during the Covid-19 epidemic involves a complex decision-making process that includes sociological, clinical and economic factors. ${ }^{[5]}$

Although some algorithms and scoring systems have been published that determine surgical priorities in spinal surgeries, there is no publication in the literature that shares authors'experience on spinal deformities such as scoliosis and kyphosis surgery during the pandemic period. In our study, we aimed to contribute to the literature by sharing our experiences with major spine surgeries such as scoliosis and kyphosis surgery in juvenile and adolescent patients in one year period of the Covid-19 pandemic.

\section{MATERIAL AND METHOD}

We retrospectively evaluated a total of 26 juvenile and adolescent idiopathic scoliosis and kyphosis patients we operated in a year starting from April 2020, when pandemic measures were implemented in our country, up to April 2021. The demographic characteristics and diagnoses of the patients are presented in Table 1. In line with the current guidelines published by the Ministry of Health, all patients before surgery were questioned in terms of viral symptoms such as fever, sore throat, cough, myalgia, shortness of breath or anosmia, and were evaluated by performing Covid-19 PCR test and blood tests 24 hours in advance, regardless of clinical symptoms. Written informed consent was obtained from the relatives of the patients by explaining the complications that may develop due to Covid-19 infection during the pandemic. After the Covid-19 diagnosis was excluded, they were operated on. Postoperative length of stay and early and late complications of the patients were recorded. The patients were intubated in line with the current guidelines of the Ministry of Health. Neuromonitoring was used routinely during the operations, and no pathological finding was found in the neuromonitor parameters during the operation. Patients who were kept in the recovery room for sufficient time after being extubated were then admitted to single rooms in the service. Paracetamol and morphine were given for pain control. The patients who were mobilized with a corset on the second day were discharged on the fifth day (Figure 1.a,b). All protocols were approved by Ethics Committee of Bursa Hospital (05.05.2021-2020-8/3).

\section{RESULTS}

Average amount of blood loss per case was $600 \mathrm{ml}$. and the average operative time was 4 hours and 23 minutes. No major respiratory complications were observed in the patients during the intraoperative and / or postoperative period. One patient was found to have Horner syndrome 10 days after discharge, and the right-sided T1 screw was removed by revision surgery. In another patient, the L1 screw was revised as it touched the spinal root from the medial of the pedicle. No patients had symptoms and signs of Covid-19 during the one-month follow-up after discharge, including revision surgeries performed on these two patients (Table 1).

\section{DISCUSSION}

In the coronavirus pandemic, as the healthcare system and hospitals primarily use their resources to combat the epidemic, it has led to an accumulation of patients awaiting major surgeries such as spinal deformities. ${ }^{[6]}$ In such a pandemic environment, daily medical practices have been rediscovered for every medical field. ${ }^{[7]}$ Due to the suspension of most elective surgeries worldwide, many surgeons had to work in Covid outpatient clinics and wards. This situation had negative effects on surgeons. ${ }^{[8]}$

During the pandemic, in accordance with the guidelines formulated by the French Spine Surgery Society, it was recommended that the operations be postponed to a later date for spinal deformities (scoliosis and kyphosis). ${ }^{[7]}$ Similarly Sciubba DM et al. ${ }^{[9]}$ determined surgical priorities with the scoring system designed by them but left the decision to the surgeon who performed the surgery. Neurosurgical operations were divided into five categories during the pandemic by the American College of Surgeons, and an algorithm was created accordingly. ${ }^{[10]}$ According to these publications by spine surgeons, some have defined algorithms for the recovery of neurological functions and pain reduction, while others have published algorithms for preserving lung function, managing infection and preventing neurological damage. ${ }^{[1]}$

The existence of asymptomatic carriers and evidence that they have viral loads similar to symptomatic patients and that PCR-negative patients may have been infected with Covid-19, shows that surgeries pose a high risk for both healthcare professionals and patients. ${ }^{[1]}$ Various measures have been proposed to limit the spread of Covid-19 infections during surgery. ${ }^{[12]}$ In addition, it is important to protect patients from Covid-19 infection in the postoperative period. New guidelines have been developed in addition to existing standard precautions to protect healthcare workers against the high contagiousness of this viral disease. ${ }^{[10]}$ 


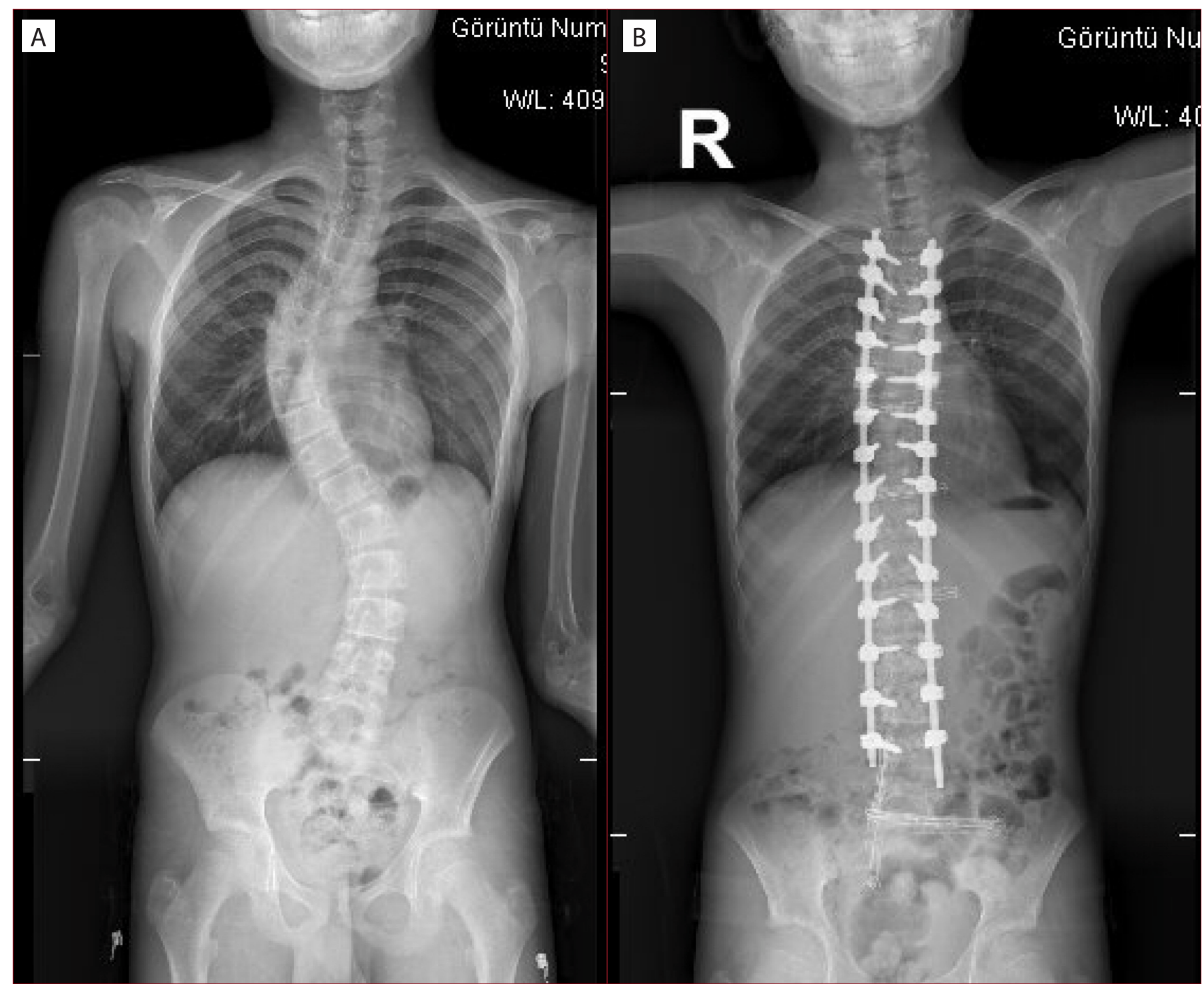

Figure $\mathbf{1}(\mathbf{a}, \mathbf{b})$. Scoliosis X-ray image of a patient, before (a) and after (b) surgery

Although neurosurgical patients are generally middle-aged or older and the mortality rate for Covid-19 is significantly higher in older adults, those with various cardiopulmonary comorbidities, brain or spine tumors and/or receiving chemotherapy ${ }_{1}^{[13,14]}$ patients we operated with the diagnosis of spinal deformity were juvenile and adolescent patients Covid-19 infection is essentially asymptomatic or mild in juvenile and adolescent individuals. ${ }^{[15,16]}$ Especially parents should be aware that the delayed risks of diseases such as spinal deformity may be higher than the risks that Covid-19 may cause. ${ }^{[17]}$

While the burden of emergency neurosurgical procedures remained unchanged throughout the pandemic, the burden of non-emergency elective cases was significantly reduced. These surgeries have shown that, especially with strict screening for Covid-19 infections, neurosurgical procedures can be performed safely in the pandemic phase. ${ }^{[18]}$
In the beginning, it was understood that the pandemic was difficult to overcome in a short time due to reasons such as failure to discover the vaccine within a short time, the fact that the whole world could not be vaccinated in a short time after the vaccine was found, an infected person could be re-infected, so we arrived at a conclusion that the surgical treatment of progressive and important spinal diseases such as scoliosis and kyphosis will not be delayed for a long time. We contacted with the families of the patients and reached a consensus that treatment should not be refused due to the fear of infection, and we performed these operations by taking the necessary precautions. According to our knowledge, there is no risk specific to Covid-19 for elective spine surgeries. ${ }^{[19]}$ Our study supports this fact.

This study has certain limitations. Patients with adult degenerative kyphosis or scoliosis were not included in our study. This prevented the generalizability of the results. 
Table 1. The demographic characteristics, diagnoses, operation time, fusion levels, complications etc. of the patients






\section{CONCLUSION}

In spite of all these disadvantages, we performed these surgeries by taking the necessary precautions in order to prevent development of overwhelming problems caused by not being operated on spinal deformities during the pandemic, and as a result, we found that these surgeries did not cause serious problems. During this pandemic crisis, successful surgical management of spinal deformities without infecting healthcare personnel was achieved. At the same time, Covid-19 infection or any complications were not observed in patients we operated during the perioperative and postoperative follow-up period.

\section{ETHICAL DECLARATIONS}

Ethics Committee Approval: Approval for the study was obtained from the Ethics Committee of Bursa City Hospital (05.05.2021-2020-8/3).

Informed Consent: Because the study was designed retrospectively, no written informed consent form was obtained from patients.

\section{Referee Evaluation Process: Externally peer-reviewed.}

Conflict of Interest Statement: The authors have no conflicts of interest to declare.

Financial Disclosure: The authors declared that this study has received no financial support.

Author Contributions: All of the authors declare that they have all participated in the design, execution, and analysis of the paper, and that they have approved the final version.

\section{REFERENCES}

1. Anari JB, Baldwin KD, Flynn JM, Cahill PJ. What's Important: Managing the Impact of Coronavirus on Pediatric Spine Surgery. J Bone Joint Surg Am 2020;102:e94.

2. Ramo B, Tran DP, Reddy A, et al. Delay to Surgery Greater Than 6 Months Leads to Substantial Deformity Progression and Increased Intervention in Immature Adolescent Idiopathic Scoliosis (AIS) Patients: A Retrospective Cohort Study. Spine Deform 2019;7:428-35.

3. Miyanji F, Slobogean GP, Samdani AF, et al. Is larger scoliosis curve magnitude associated with increased perioperative health-care resource utilization?: a multicenter analysis of 325 adolescent idiopathic scoliosis curves. J Bone Joint Surg Am 2012;94:809-13.

4. Miyanji F, Newton PO, Samdani AF et al. Impact of surgical waiting-list times on scoliosis surgery:the surgeon's perspective. Spine (Phila Pa 1976) 2015;40:823-8.

5. Rizkalla JM, Hotchkiss W, Clavenna A, Dossett A, Syed IY. Triaging Spine Surgery and Treatment during the COVID-19 Pandemic. J Orthop 2020;20:380-5.

6. Liu G, Tan JH, Hey HWD, et al. A novel hospital capacity versus clinical justification triage score (CCTS) for prioritization of spinal surgeries in the "new normal state" of the COVID-19 pandemic. Eur Spine J 2021;30:1247-60.

7. Prost S, Charles YP, Allain J, et al. French Spine Surgery Society guidelines for management of spinal surgeries during COVID-19 pandemic. World J Clin Cases 2020;8:1756-62.

8. Louie PK, Harada GK, McCarthy MH et al. The Impact of COVID-19 Pandemic on Spine Surgeons Worldwide. Global Spine J 2020;10:534-52.
9. Sciubba DM, Ehresman J, Pennington Z, et al. Scoring System to Triage Patients for Spine Surgery in the Setting of Limited Resources:Application to the Coronavirus Disease 2019 (COVID-19) Pandemic and Beyond. World Neurosurg 2020;140:e373-e380.

10. Arnaout O, Patel A, Carter B, Chiocca EA. Letter:Adaptation Under Fire:Two Harvard Neurosurgical Services During the COVID-19 Pandemic. Neurosurgery 2020;87:E173-E177.

11. Zou L, Ruan F, Huang M et al. SARS-CoV-2 viral load in upper respiratory specimens of infected patients. N Engl J Med 2020;382:1177-9.

12. Reed LK, Wen J, Liang B, Wang X, Feng D, Huang JH. Safely performing neurosurgical procedures during COVID-19 pandemic. Neurol. Res 2020;42:811-7.

13. Al-shamsi HO, Alhazzani W, Alhuraiji A et al. A practical approach to the management of cancer patients during the novel coronavirus disease, (covid-19) pandemic:an international collaborative group. Oncologist 2020;25:e936-e945.

14. Guan WJ, Liang WH, Zhao $Y$ et al. Comorbidity and its impact on 1590 patients with Covid- 19 in China:A Nationwide Analysis. Eur Respir J 2020;55:2000547.

15. Maltezou HC, Magaziotou I, Dedoukou X et al. Children and Adolescents With SARS-CoV-2 Infection:Epidemiology, Clinical Course and Viral Loads. Pediatr Infect Dis J 2020;39:e388-e392.

16. Shen K, Yang Y, Wang T et al. Diagnosis, treatment, and prevention of 2019 novel coronavirus infection in children:experts' consensus statement. World J Pediatr 2020;16:223-31.

17. Lazzerini M, Barbi E, Apicella A, Marchetti F, Cardinale F, Trobia G. Delayed access or provision of care in Italy resulting from fear of COVID-19. Lancet Child Adolesc Health 2020;4:e10-e11.

18. Bajunaid K, Alatar A, Alqurashi A et al. The longitudinal impact of COVID-19 pandemic on neurosurgical practice. Clin Neurol Neurosurg 2020;198:106237.

19. Viswanathan VK, Subramanian S, Rao AK. Principles for Managing Patients with Spinal Ailments in the Coronavirus Disease 2019 Era:What Do We Know So Far? An Evidence-Based, Narrative Review. Asian Spine J 2020; 14:572-80. 